\title{
Stable isotope studies on the origin and geological history of water and salts in the Lake Vanda area, Antarctica
}

\author{
Nobuyuki Nakai, Hideki Wada, Yasuhiro KiYosu \\ and MiKIO TAKIMOTO \\ Department of Earth Sciences, Faculty of Science, \\ Nagoya University, Chikusa, Nagoya, 464 Japan
}

(Received December 18, 1974)

\begin{abstract}
Possible origins of lake water, salts dissolved in water of a saline lake, Lake Vanda, those contained in cored sediments of the lake and those distributed on the ground surface in the adjacent area were investigated on the basis of the stable isotope compositions, ${ }^{13} \mathrm{C} /{ }^{12} \mathrm{C}$, ${ }^{18} \mathrm{O} /{ }^{16} \mathrm{O}$ and ${ }^{34} \mathrm{~S} /{ }^{32} \mathrm{~S}$.

The lake water is concluded to be neither marine nor volcanic in origin but surface fresh water such as glacial melt water, because of the low $\delta^{18} \mathrm{O}$ values ranging from -30.3 to $-31.9 \%$. On the other hand, sulfate in lake water and in cored sediments from Lake Vanda shows $\delta^{34} \mathrm{~S}$ values similar to that of sea water sulfate. Therefore, it is supposed to be marine in origin.

Salts distributed on the ground surface near the lake consist mainly of calcite, gypsum, thenardite, sodium niter and halite. The isotopic compositions of carbonate and sulfate minerals range from -14.4 to $+17.6 \%$ for $\delta^{13} \mathrm{C}$ and from -0.4 to $+22.3 \%$ for $\delta^{18} \mathrm{O}$ of calcite and from +14.1 to $+20.3 \%$ for $\delta^{34} \mathrm{~S}$ of gypsum. From the isotopic compositions of calcite and gypsum, three different origins, hydrothermal, marine and marine aerosol are considered according to their occurrences and localities. Salts distributed in this area, however, do not constitute the source for those contained in Lake Vanda.

The genesis and historical events of the saline lake also were examined. The lake was once a fjord containing sea water and was isolated from the ocean by glaciation after the Tertiary. After the isolation of the lake from the ocean, evaporation of lake water in cold climate and supply of glacial melt water in warm climate have alternately taken place several times.
\end{abstract}

\section{INTRODUCTION}

A large ice-free area, referred to as 'Dry Valleys' area, exists in southern Victoria Land on the west side of McMurdo Sound, Antarctica. The area consists of several eastwest trending, glacially eroded valleys and intervening mountains. One of these deglaciated valleys, Wright Valley remains essentially free of snow and ice all the year round, reflecting the arid climate in this area. This valley is blocked by Wright Lower Glacier $25 \mathrm{~km}$ east and by Wright Upper Glacier $17 \mathrm{~km}$ west of Lake Vanda.

Lake Vanda is situated in the west of Wright Valley, about $50 \mathrm{~km}$ west of the east coast of Victoria Land $\left(77^{\circ} 32^{\prime} \mathrm{S}, 161^{\circ} 30^{\prime} \mathrm{E}\right)$ and occupies the lowest part of the valley at the hight of $95 \mathrm{~m}$ above sea level (Fig. 1). It is approximately $5.6 \mathrm{~km}$ long, $1.4 \mathrm{~km}$ wide and up to $68 \mathrm{~m}$ deep. The lake is perennially covered with $4 \mathrm{~m}$ thick ice. During summer, however, a moat of melt water with a few meters width forms at the lake margin. The lake is supplied with glacial melt water from the east via the Onyx River which drains 
mainly the Wright Lower glacier, has no outflow and water is lost only by evaporation.

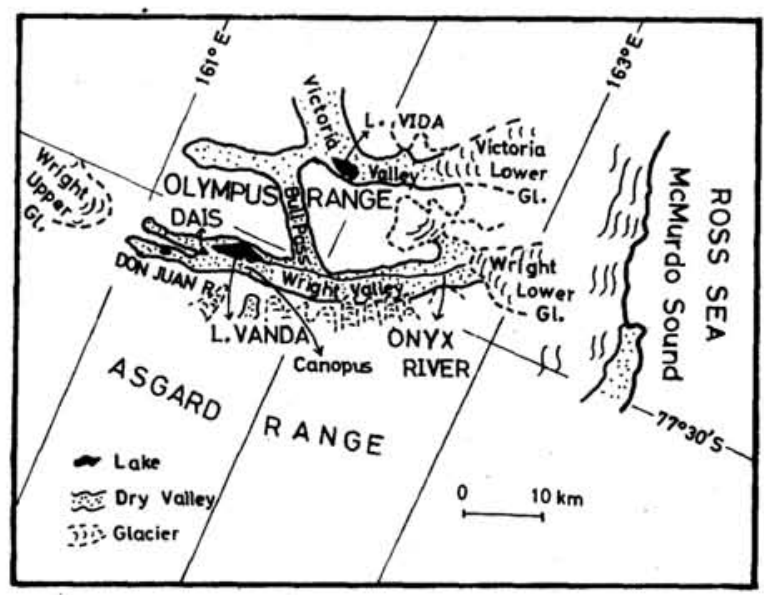

Fig. 1. Map of Dry Valleys, Victoria Land, Antarctica.

Lake Vanda is distinguished by the following three specific features of its bottom water layers.

(1) Relatively high temperature

The water temperature increases gradually with depth and reaches the highest value of 24.5 to $25.7^{\circ} \mathrm{C}$ at the bottom layer in spite of the mean annual air temperature of about $-20^{\circ} \mathrm{C}$ (Wilson and Wellman, 1962; Ragotzkie and LiKeno, 1964; Hoare 1966; TORII et al., 1967; Yoshida et al., 1971).

(2) The presence of dense water

The lake water is permanently density-stratified by the salt concentration. The chemocline which coincides approximately with thermocline begins between the depths of 40 and $50 \mathrm{~m}$. The smallest salinity of $\mathrm{n} \times 10 \mathrm{mg} \mathrm{Cl}-11$ was observed just underneath the surface ice sheet and the highest chloride content up to $75.88 \mathrm{~g} / 1$ for the bottom water (Yamagata et al., 1967).

(3) High concentration of $\mathrm{H}_{2} \mathrm{~S}$

According to Yoshida et al. (1971), the $\mathrm{H}_{2} \mathrm{~S}$ content of lake water near the bottom was up to $32.6 \mathrm{mg} / 1$. Author's analyses of 1973 -samples gave values up to $76.8 \mathrm{mg} / 1$ at the depth of $68 \mathrm{~m}$.

Many investigators had attempted to elucidate the above characteristic features and to trace the geologic history of Lake Vanda as a clue to the Antarctica's past. On the basis of significant information obtained so far, however, even the origin of salts in the lake can not be definitely disclosed yet. A new source of information, therefore, is required. The past of a lake may be disclosed by studies of bottom sediments which keep the record of geologic events occurred in the past.

The Dry Valley Drilling Project (DVDP) was initiated in 1971 to start airborne and surface geological and geophysical studies. The first drilling started in early 1973 on Ross Island. During 1973 1974 field survey season, DVDP \#4 hole was drilled near the center of Lake Vanda and sediments were collected with a core sampler. In this study, the origin of salts dissolved in water and contained in sediments of the lake and 
distributed in the adjacent areas is investigated on the basis of the stable isotopic compositions. The origin of water itself also is examined, and the genesis and historical events of the saline lake are discussed in the following sections.

\section{SAmples and SAmpling Localities}

Cored unconsolidated sediments In November 1973, DVDP \#4 drilling was performed to obtain unconsolidated sediments of Lake Vanda. The drilling site was set on the surface of ice near the center and over the deepest point of the lake, which is approximately $68.3 \mathrm{~m}$ below the ice surface. Cored sediments were successfully sampled about $11.2 \mathrm{~m}$ long to reach basement granite at the depth of $80.7 \mathrm{~m}$ below the ice surface. Sediments are unconsolidated, black to brown in color and sandy to silty in grain size. They contain generally less than 5 per cent of pebbles and granules of gray gneiss, granitic rocks, diabase and quartz arenite.

A few unconsolidated gravel layers were found in the sediments. The first of two main gravel layers in glacial sediments is approximately $50 \mathrm{~cm}$ in thickness and lies at the depth of $72 \mathrm{~m}$ below the ice surface. The second gravel layer is $30 \mathrm{~cm}$ in thickness at the depth of $75 \mathrm{~m}$ below the ice surface.

Several bands of salts which consist of gypsum and calcite were found in the upper few meters of sediments above the first glacial gravel layer.

Lake water and ground water samples Water samples of Lake Vanda were collected vertically at the site near the center of the lake where DVDP \#4 drilling was performed. Ground water samples were collected from two gravel layers through the casing during drilling.

Ice (permafrost) samples in cored rocks DVDP \#3 and \#6 were drilled at the McMurdo Station on Ross Island and at the shore of Lake Vida in Victoria Valley, respectively. The former was drilled to a depth of $381 \mathrm{~m}$ and the cored samples consist mainly of basaltic and pyroclastic rocks. The latter reached a depth of $330 \mathrm{~m}$, consisting mostly of granite gneiss. In both \#3 and \#6 drilling cores, ice occurred in cavities, vesicles and fractures. The ice was analyzed for oxygen isotope composition.

Salts distributed around Lake Vanda Deposits of salts were found on the surface of rock debris and in soils extensively around Lake Vanda. The minerals of these salts were identified by MoRIKAwa and OssaKa (1974) to be gypsum, thenardite, calcite, sodium niter and halite. Besides the salt deposits on the land surface, gypsum, thenardite and dolomite occur with zeolite (laumontite) and chlorite in veins of dolerite which constitutes the Dais near Lake Vanda.

\section{EXPERIMENTAL}

Temperature and $\mathrm{pH}$ were determined in situ for lake water and ground water. Hydrogen sulfide dissolved in water was fixed as CdS immediately after collecting water samples to prevent oxidation. $\mathrm{SO}_{4}^{z}$ and $\mathrm{H}_{2} \mathrm{~S}$ contents were determined by the ordinary gravimetric methods. ${ }^{13} \mathrm{C} /{ }^{12} \mathrm{C},{ }^{18} \mathrm{O} /{ }^{16} \mathrm{O}$ and ${ }^{34} \mathrm{~S} /{ }^{32} \mathrm{~S}$ ratios were determined with a Varian Mat $\mathrm{CH} 7$ mass spectrometer. These ratios are expressed in permil deviations from 
standards as follows,

$$
\delta^{13} \mathrm{C}, \delta^{18} \mathrm{O} \text { or } \delta^{34} \mathrm{~S}(\%)=\frac{R_{\mathrm{X}}-R_{\text {st. }}}{R_{\text {st. }}} \times 1,000,
$$

where $R_{\mathrm{X}}$ and $R_{\text {st. denote }}{ }^{13} \mathrm{C} /{ }^{12} \mathrm{C},{ }^{18} \mathrm{O} /{ }^{16} \mathrm{O}$ or ${ }^{34} \mathrm{~S} /{ }^{32} \mathrm{~S}$ for samples and standards, respectively. PDB (Belemnitella americana from the Cretaceous PeeDee formation, South Carolina), SMOW (Standard mean ocean water) and troilite sulfur in the Canyon Diablo meteorite were used as standards for carbon, oxygen and sulfur, respectively.

\section{RESUlts AND Discussion}

Origin of the lake water The analytical results for lake and ground waters are listed in Table 1, with data of lake water sampled by TORII and HASHIMOTo in 1972. The $\delta^{18} \mathrm{O}$ values for lake waters collected in 1972 and 1973 agree with each other rather well, although values in 1972 are slightly higher than those for 1973-samples $(-30.3 \sim-31.9 \%$. These small values suggest that the lake water is not marine in origin. Since evaporation of water from the lake could only have increased these values, such low ${ }^{18} \mathrm{O}$ concentrations of lake water can not be explained by evaporation of ocean water. Therefore, even if the salt dissolved in lake water have derived from ocean water, present water in the lake must have been supplied from other sources.

Table 1. Analytical results for lake and ground water samples from Lake Vanda

\begin{tabular}{|c|c|c|c|c|c|c|c|c|c|}
\hline \multirow{2}{*}{\begin{tabular}{c|} 
Depth* \\
$(\mathrm{m})$
\end{tabular}} & \multirow{2}{*}{$\frac{\text { Temp. }}{\left.{ }^{\circ} \mathrm{C}\right)}$} & \multirow{2}{*}{$\mathrm{pH}$} & \multicolumn{2}{|c|}{$\delta^{18} \mathrm{O}\left(\mathrm{H}_{2} \mathrm{O}\right) \%$} & \multicolumn{3}{|c|}{$\mathrm{SO}_{4}^{=}$} & \multicolumn{2}{|c|}{$\mathrm{H}_{2} \mathrm{~S}$} \\
\hline & & & $19.72 * *$ & 1973 & $(\mathrm{mg} / 1)$ & $\delta^{18} \mathrm{O}^{* 0 * *} \%$ & $\delta^{34} \mathrm{~S}(\% 00)$ & $(\mathrm{mg} / 1)$ & $\delta^{34} \mathrm{~S}(\%)$ \\
\hline \multicolumn{10}{|c|}{ Water column } \\
\hline 4 & \begin{tabular}{|l|}
3.0 \\
\end{tabular} & 7.80 & -30.3 & -30.7 & 8.7 & - & +15.0 & 0.0 & - \\
\hline 8 & 5.0 & 7.98 & - & -31.0 & 12.6 & - & +15.9 & 0.0 & - \\
\hline 12 & 6.0 & 8.02 & - & -30.9 & 12.4 & - & +15.5 & 0.0 & - \\
\hline 16 & 7.5 & 7.78 & - & -31.4 & 18.9 & - & +15.8 & 0.0 & - \\
\hline 20 & 7.5 & 7.75 & -31.0 & -31.4 & 20.2 & - & +16.0 & 0.0 & - \\
\hline 40 & 8.2 & 7.60 & - & -31.7 & 23.5 & - & +16.6 & 0.0 & - \\
\hline 45 & 10.2 & 7.55 & - & -31.8 & 27.2 & - & +17.5 & 0.0 & - \\
\hline 50 & 15.0 & 6.82 & - & -31.9 & 55.3 & - & +18.7 & 0.0 & - \\
\hline 55 & 20.9 & 5.98 & -31.2 & -31.6 & 235 & -10.0 & +22.0 & 0.0 & - \\
\hline 60 & 24.7 & 5.95 & -31.0 & -31.1 & 237 & -9.9 & +22.5 & 0.0 & - \\
\hline 65 & 24.8 & 5.65 & -29.9 & -30.4 & 606 & +6.0 & +42.1 & 53.4 & +7.7 \\
\hline 68 & - & 5.60 & - & -30.3 & 611 & +6.2 & +46.0 & 78.6 & +10.5 \\
\hline \multicolumn{10}{|c|}{ Ground water in sediments } \\
\hline 72 & 8.0 & 6.3 & - & -28.5 & 573 & - & +48.8 & 0.5 & - \\
\hline 75 & 12.2 & 6.3 & - & -27.7 & 345 & - & +39.1 & 0.5 & - \\
\hline
\end{tabular}

The low ${ }^{18} \mathrm{O}$ concentration of lake water suggests that its source is to be surface fresh water. The evidence for surface fresh water may be given by $\delta^{18} \mathrm{O}$ measurements of permafrost in cored samples from DVDP \#3 and \#6. Figure 2 is a plot of $\delta^{18} \mathrm{O}$ values against the depth. As shown in this figure, the value gradually increases with increasing depth, varying from -34.2 to $-0.1 \%$ at the depths of 11.39 to $330.10 \mathrm{~m}$ and from 


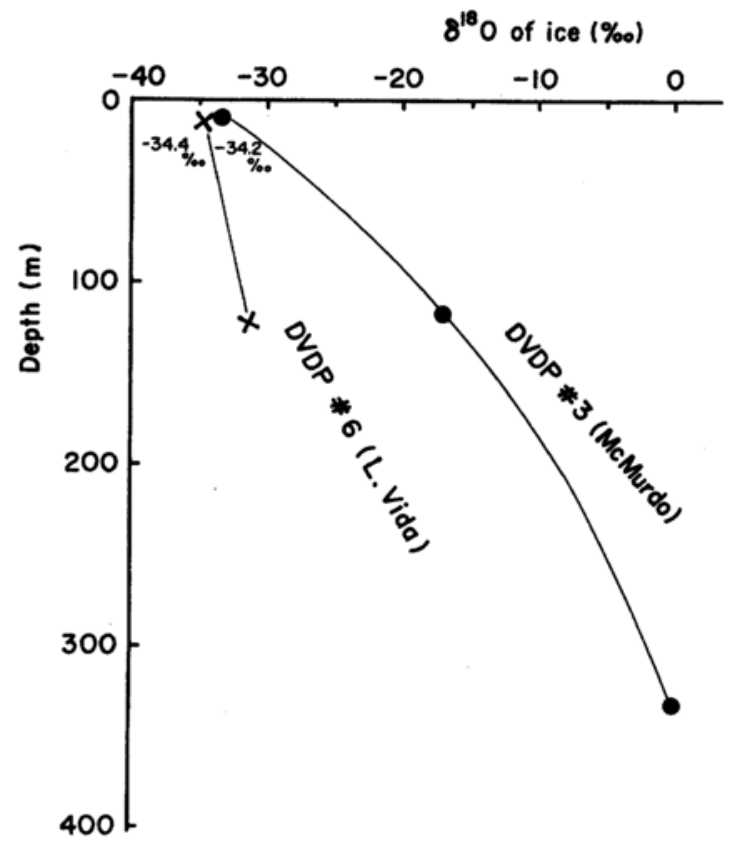

Fig. 2. Vertical distribution of $\delta^{18} \mathrm{O}$ for permafrost from DVDP \#3 (McMurdo) and \#6 (Vida) drillings.

-34.4 to $-32.0 \%$ at the depths of 10.83 to $121.5 \mathrm{~m}$, in DVDP \#3 and DVDP \#6, respectively. $\delta^{18} \mathrm{O}$ values of ice near the ground surface apparently converge to -34 to $-34.5 \%$ for both drilling cores. LYON (1974) reported that $\delta^{18} \mathrm{O}$ values of ice from DVDP \#2 and \#3 are about $-33 \%$ near the ground surface. Furthermore, the value of snow accumulating on the ice shelf in McMurdo Sound ranges from -32 to $-34 \%$ (JoHNson et al., 1972). In general, concentrations of heavy isotopes in fresh water decrease with increasing latitude and altitude (DANSGAARD, 1954), and these values are considered to be typical as those of fresh water in this area (DANSGAARD, 1964). If thermal or magmatic waters could have contributed as supposed from relatively high temperature of the bottom lake water, $\delta^{18} \mathrm{O}$ should be much higher (WhITE, 1973).

All $\delta^{18} \mathrm{O}$ values for lake water samples are in the $\delta^{18} \mathrm{O}$ value ranges of ice occurring near the top of drilling cores, present day precipitation in this area and water flooding into the lake $(-29.5 \%$ ). Present day water of the lake in arid 'Dry Valleys' is concluded to have originated mainly from melt water of glaciers.

The vertical distribution of $\delta^{18} \mathrm{O}$ is shown in Fig. 3. The minimum value, $-31.9 \%$, was observed at the depth of $50 \mathrm{~m} .{ }^{18} \mathrm{O}$ concentration sharply increases with depth especially below $50 \mathrm{~m}$, and the highest $\delta^{18} \mathrm{O}$ value, $-27.7 \%$, was observed for ground water in the second gravel layer at the depth of $75 \mathrm{~m}$ below the lake surface. Therefore, water which is enriched in ${ }^{18} \mathrm{O}$ is supposed to have been included in sediments of the deep lake basin. The isotope data suggest that the lake water in deep layers is a remnant resulted from evaporation of fresh water or may be a trace of sea water.

On the other hand, surface lake water shows $\delta^{18} \mathrm{O}$ values of $-30.7 \%$ which is similar to or somewhat lower than that of inflowing water. Present surface water of the lake, therefore, is assumed to have resulted from mixing of inflowing water from Wright Lower Glacier and lake water with low $\delta^{18} \mathrm{O}$ values in middle layers. 


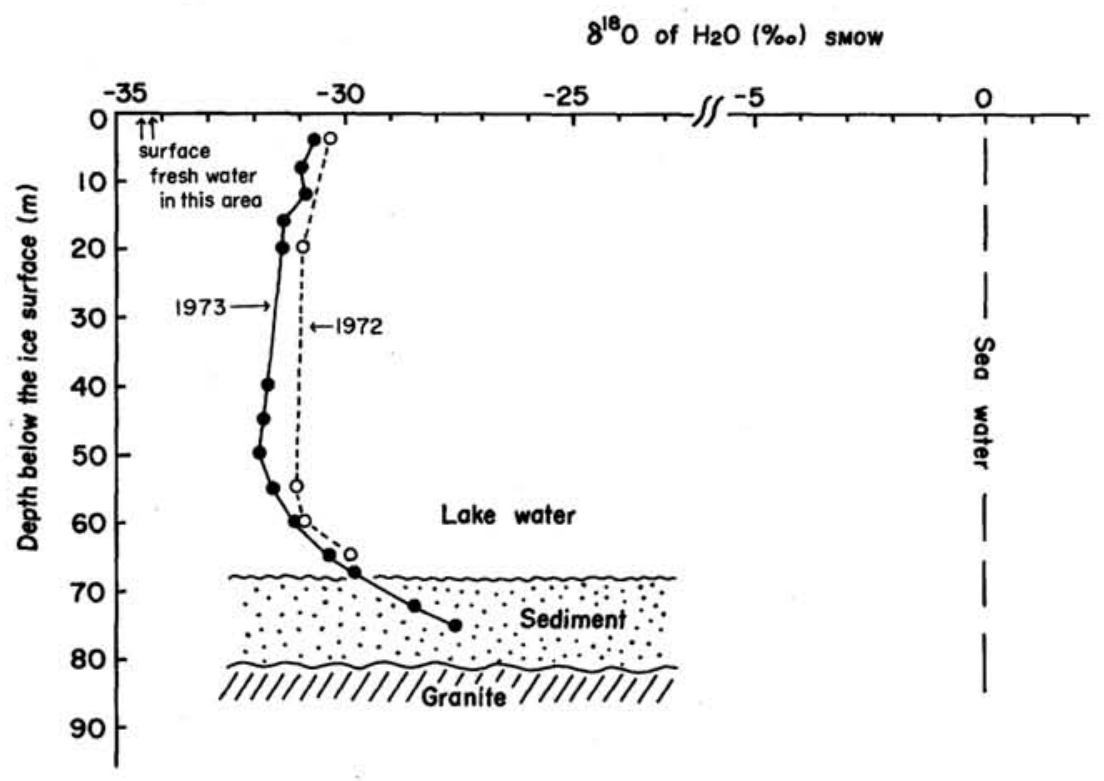

Fig. 3. Vertical distribution of $\delta^{18} O$ for water in Lake Vanda.

Regarding the minimum $\delta^{18} \mathrm{O}$ values in the middle layers, the isotopic composition can not be explained simply by mixing of surface and bottom waters and by the isotopic fractionation through physical processes such as evaporation and freezing of lake waters. Other possible sources of water must be considered. The ${ }^{18} \mathrm{O}$ concentrations of precipitations and glaciers tend to be smaller with increasing altitude and distance from the coast, as expected from the results obtained by DANSGAARD (1954, 1964), FriEDMAN et al. (1964) and others. As mentioned above, this Wright Valley is blocked by glaciers at both ends, and the present lake is supplied with water only by the Onyx River from Wright Lower Glacier. Between the lake and Wright Upper Glacier, however, an old stream bed can be recognized, suggesting that once glacial melt water flowed into the lake from the west. The melt water would have been more depleted in ${ }^{18} \mathrm{O}$ than that of Wright Lower Glacier, because Wright Upper Glacier is situated at a higher altitude, above $2,000 \mathrm{~m}$, and in an area distant from the coast. It is, therefore, probable that once the water of $10{ }^{18} \mathrm{O}$ in middle layers was supplied from Upper Glacier. Numerous ancient shorelines are visible around the lake, the highest resting approximately $55 \mathrm{~m}$ above the present lake surface. They suggest that the level of the lake surface has fluctuated largely, extending probably to some depths, and melt water of Upper Glacier possibly flowed into the level of the present middle layers of the lake.

\section{Origin of salts in the lake and historical events}

1) Salts dissolved in waters

As shown in Table 1, high concentrations of salts and exceptionally high temperatures were observed in bottom layers of the lake water. High concentrations of $\mathrm{H}_{2} \mathrm{~S}$ up to $78.6 \mathrm{mg} / 1$ could be found. Regarding the origin of the salts dissolved in water, many investigators have suggested following possibilities on the source. 
(a) Salts, $\mathrm{H}_{2} \mathrm{~S}$ and heat energy were supplied from the lake bottom by hot springs. This is supported by the fact that this valley is located in the Ross Island volcanic area (Armitage and House, 1962; Angino et al., 1962, 1965).

(b) High salt concentrations resulted from evaporation of sea water after the lake was isolated from the ocean (Angino and Armitage, 1963; Craig 1966; Nichols, 1963).

(c) Salts were leached from evaporite beds occurred in sedimentary rocks.

(d) Salts were supplied mainly by wind from the ocean (Nichols, 1963; ANGino et al., 1965.

(e) Salts were formed by chemical weathering of bed rocks and soils (JONES and FAURE, 1965).

Most workers suggested multiple sources to account for all the salts and the origin of salts in lake water is thus still controversial.

In this study, isotopic compositions and concentrations of sulfur compounds were determined for lake water samples. The data are listed in Table 1 and are shown graphically in Figs. 4 and 5. The concentration of $\mathrm{SO}_{4}^{=}$varies with depth, ranging from $8.7 \mathrm{mg} / 1$ just under the surface ice to $611 \mathrm{mg} / 1$ of bottom water at the depth of $68 \mathrm{~m}$ below the ice surface. Discontinuities in the concentration profile occur at approximately 15 and $55 \mathrm{~m}$ below the surface. In the ground water, the concentration decreases with depth. $\mathrm{H}_{2} \mathrm{~S}$ appears only in bottom layers below the discontinuity at the depth of $50 \mathrm{~m}$ and almost disappears in ground waters, being probably fixed as metal sulfides in sediments. Vertical distribution of $\mathrm{SO}_{4}^{=}$and $\mathrm{H}_{2} \mathrm{~S}$ show clearly that they were not supplied from bed rocks and lake sediments.

The vertical variation of $\delta^{34} \mathrm{~S}$ values is shown in Fig. 5. $\delta^{34} \mathrm{~S}$ values of $\mathrm{SO}_{4}^{=}$increase with depth, especially sharply below the depth of $60 \mathrm{~m}$, where $\mathrm{H}_{2} \mathrm{~S}$ appears, and the maximum value reaches $+48.8 \%$. On the other hand, $\delta^{34} \mathrm{~S}$ values of $\mathrm{H}_{2} \mathrm{~S}$ range from +7.7 to $+10.5 \%$. The difference of $\delta^{34} \mathrm{~S}$ values between $\mathrm{SO}_{4}^{\bar{z}}$ and coexisting $\mathrm{H}_{2} \mathrm{~S}$ is

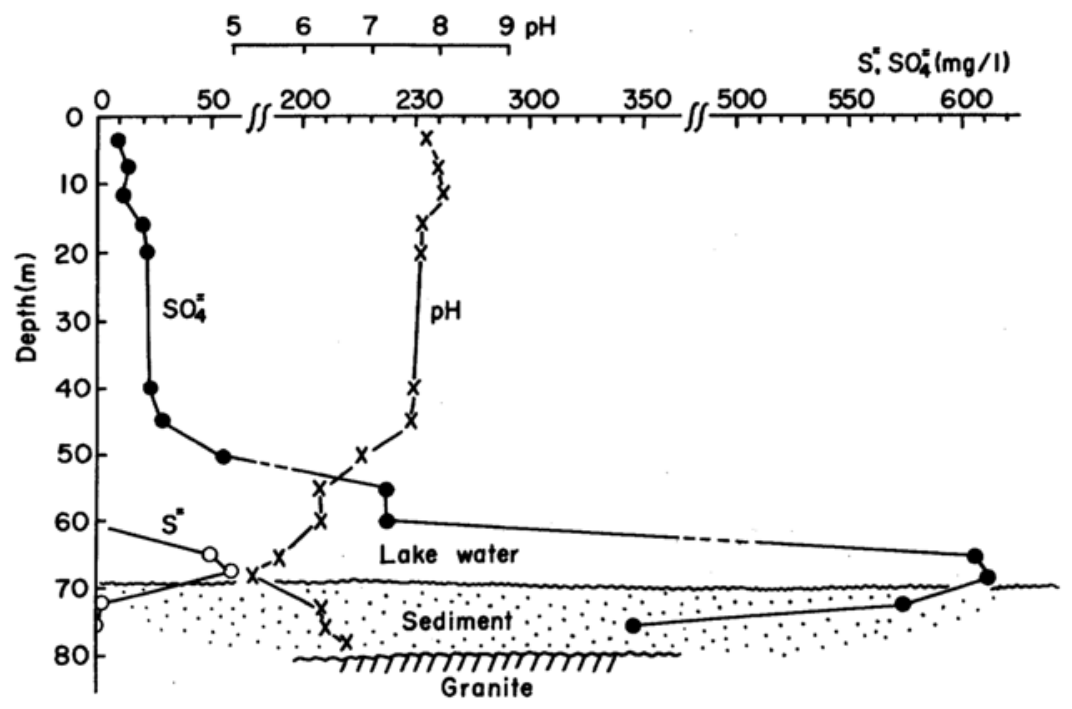

Fig. 4. Vertical variations of $\mathrm{SO}_{4}^{=}$and $\mathrm{S}^{=}$contents and $\mathrm{pH}$ of water in Lake Vanda. 


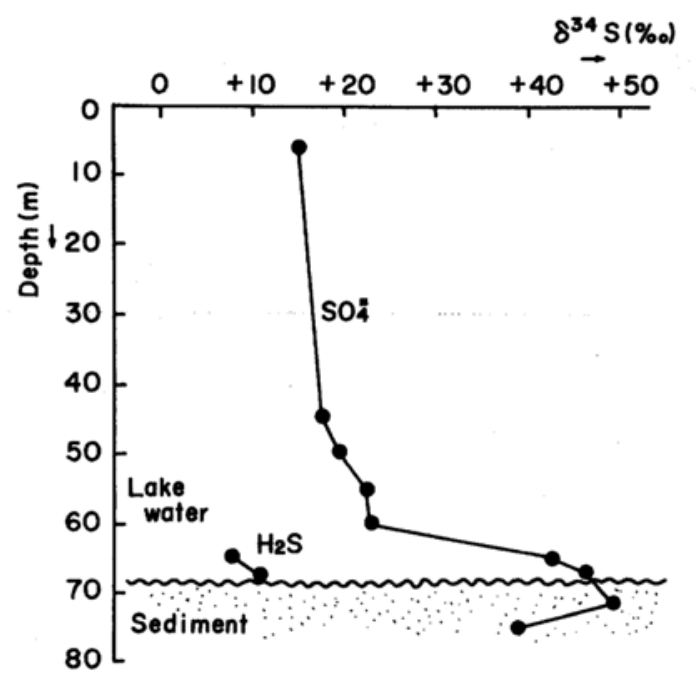

Fig. 5. Vertical distribution of $\delta^{34} S$ for $\mathrm{SO}_{4}^{\equiv}$ and $\mathrm{S}^{\mathrm{E}}$ in Lake Vanda.

calculated to be 34.4 to $35.5 \%$. Such large fractionations can not be explained by high temperature products of volcanic activities, but by bacterial reduction of $\mathrm{SO}_{4}^{=}$to $\mathrm{H}_{2} \mathrm{~S}$ (NAKAI and JENSEN, 1964). $\delta^{34} \mathrm{~S}$ values of $\mathrm{H}_{2} \mathrm{~S}$ from volcanic activities are presented in Table 2, being quite different from those of the lake water. Sediments contain enough amounts of organic materials available to sulfate reducing bacteria, and the organic contents have been determined to be $6 \%$ for surface sediments (NELSON and WILSON, 1972) and $1.4 \%$ in the maximum value for cored sediments as seen in Fig. 6 (this work).

Sulfate in bottom water layers is highly enriched in ${ }^{34} \mathrm{~S}$. This is due to the isotopic fractionation in the process of bacterial reduction of $\mathrm{SO}_{4}^{=}$to $\mathrm{H}_{2} \mathrm{~S}$ in which the light isotope, ${ }^{32} \mathrm{~S}$, is preferentially reduced to $\mathrm{H}_{2} \mathrm{~S}$. In shallower water containing free oxygen, in contrast, $\mathrm{SO}_{4}^{=}$are depleted in ${ }^{34} \mathrm{~S}$ and the lowest $\delta^{34} \mathrm{~S}$ value, $+15 \%$ is observed at the depth of $4 \mathrm{~m}$ below the ice surface. Low $\delta^{34} \mathrm{~S}$ values of $\mathrm{SO}_{4}^{\overline{1}}$ in shallower layers are possibly explained by addition of secondary $\mathrm{SO}_{4}^{\bar{y}}$ produced in the bacterial oxidation of $\mathrm{H}_{2} \mathrm{~S}$ which migrated from depths to shallow water layers, because the isotopic fractionation in the process of bacterial oxidation is so small that the produced $\mathrm{SO}_{4}^{=}$are expected to have isotopic compositions similar to that of original $\mathrm{H}_{2} \mathrm{~S} . \delta^{34} \mathrm{~S}$ values of $\mathrm{SO}_{4}^{=}$in lake

Table 2. $\delta^{34} \mathrm{~S}$ of $\mathrm{H}_{2} \mathrm{~S}$ from volcanic activities in Japan

\begin{tabular}{l|r|c}
\hline & $\delta^{34} \mathrm{~S}(\%)$ & $\begin{array}{c}\text { Numbers of analyzed } \\
\text { samples }\end{array}$ \\
\hline Hot springs & & 3 \\
Tamagawa & $-7.1 \sim-1.1$ & 4 \\
Narugo & $-1.8 \sim+1.1$ & \\
Geothermal gases & & 13 \\
Matsukawa & $-6.6 \sim+3.3$ & 7 \\
Onikobe & $-2.3 \sim+3.3$ & \\
Volcanic gases & & 13 \\
Nasu & $-4.4 \sim-1.2$ & 5 \\
Showa-shinzan & $+1.7 \sim+5.1$ & 4 \\
Kusatsu & $-6.6 \sim-3.9$ &
\end{tabular}


waters near the boundary between layers with and without $\mathrm{H}_{2} \mathrm{~S}$ is approximately $+20 \%$ o and if this sulfate is assumed not to have been subjected to bacterial activities, the origin can be postulated to be marine.

Fig. 6. Vertical distribution of gypsum and organic materials in sediments of Lake Vanda.

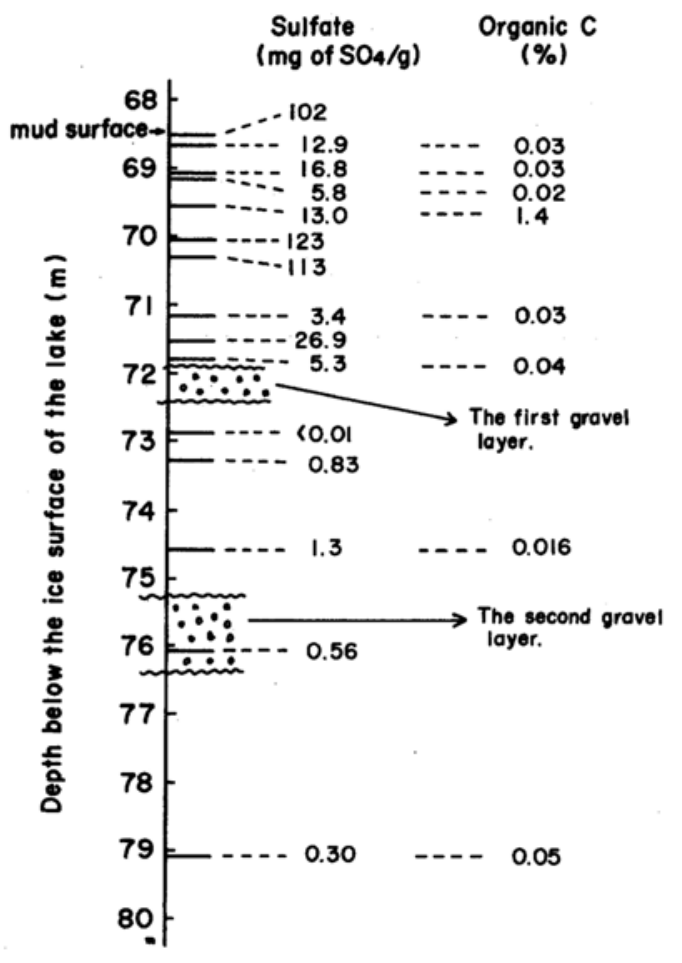

2) Salts deposited in lake sediments

As mentioned before, gypsum and calcite occur abundantly in the upper few meters of sediments. The sulfate content of sediments decreases rapidly below the first gravel layer as shown in Fig. 6 . This shows clearly that salts have been deposited after the formation of the first gravel layer (glacial gravel).

Sulfur isotopic composition of gypsum in banded salt concretions, which can be found only above the first gravel layer, is presented in Table 3. $\delta^{34} \mathrm{~S}$ values are constant, ranging from +20.4 to $+20.9 \%$, except for a sample from surface sediment. Salts having no banded structure also were analyzed for sulfur isotopic composition. Gypsum was

Table 3. $\delta^{34} \mathrm{~S}$ of gypsum concretion in Lake Vanda sediments

\begin{tabular}{ccc}
\hline \hline Sample No. & Depth $(\mathrm{m})^{*}$ & $\delta^{34} \mathrm{~S}(\%)$ \\
\hline Bottom surface & 68.3 & +22.4 \\
$1-4$ & 69.08 & +20.9 \\
$6-\mathrm{a}$ & 69.48 & +20.9 \\
$2-\mathrm{c}$ & 70.08 & +20.4 \\
$2-6$ & 70.23 & +20.9 \\
$7-5$ & 71.17 & +20.8 \\
\hline
\end{tabular}

* Below the lake surface. 
extracted repeatedly with $50 \mathrm{ml}$ each of distilled water from sediment samples until no sulfate is detected in the water extract. Sulfur isotopic values are plotted against the extraction sequence in Fig. 7. Sulfate in the first extraction is the heaviest in the extraction series. The first or early extract includes $\mathrm{SO}_{4}^{=}$, of course, from interstitial waters, $\delta^{34} \mathrm{~S}$ of which is resonably considered to have large values such as +46 to $+49 \%$ as expected for sulfate in ground and bottom waters of the lake. The progressive extraction results in a gradual decrease in $\delta^{34} \mathrm{~S}$ of extracted $\mathrm{SO}_{4}^{=}$. This approaches +20.3 to $+21.2 \%$ after 2 or 3 times of extraction for all sediment samples. This means that gypsum in sediments itself has $\delta^{34} \mathrm{~S}$ values of about +20 to $+21 \%$.

Fig. 7. $\delta^{34} S$ of sulfate repeatedly extracted from Lake Vanda sediments with distilled water.

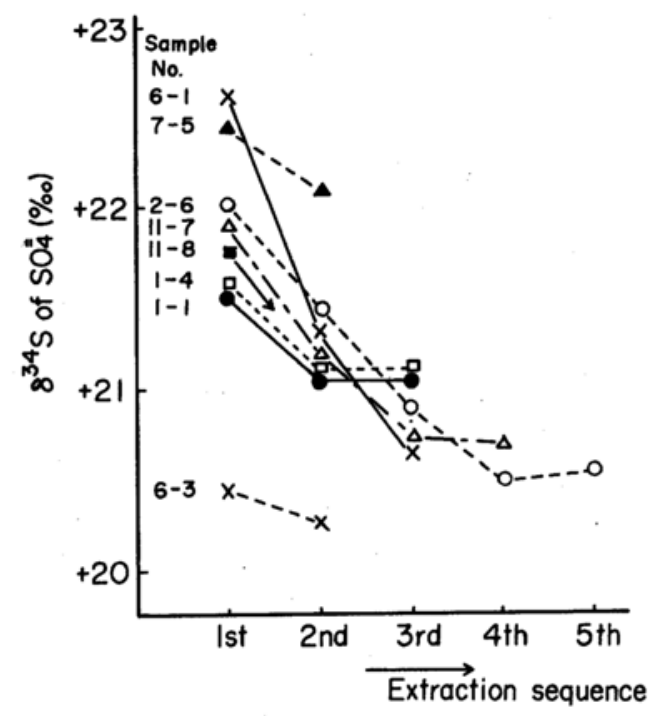

HOLSER and KAPLAN (1966) reported from isotopic studies on sulfate evaporites that the isotopic composition of oceanic sulfate largely varies with geologic age on world wide scale, and Tertiary and Recent sulfates have $\delta^{34} \mathrm{~S}$ values, which are within the range of modern sea water, $+20 \pm 2 \%$, and distinctly differ from Permian sulfate in $\delta^{34} \mathrm{~S}$. This value shows a good agreement with those of sulfate minerals analyzed in this work. On the other hand, NAKAI and JENSEN (1967) reported that $\delta^{34} \mathrm{~S}$ of atmospheric sulfate is always smaller than $+20 \%$ of sea water, ranging from 0 to $+16 \%$. Wind-transported salts, consequently, can not be accepted to have significant contribution to salts in the lake. It can be, therefore, concluded that sulfate in Lake Vanda has been derived directly from the coean, and the lake, which had been connected with the ocean, has been isolated from it since the first gravel layer (glacial gravel) was deposited by glaciation after the Tertiary. After the isolation of the lake, evaporation of lake water in cold climate and supply of fresh water such as glacial melt water in warm climate can be supposed to have alternately taken place several times, resulting in deposition and dissolution of salts, as expected from the occurrence of banded salt concretions in lake sediments.

Alternate evaporation and supply of water in the past lake can be proved by carbon and oxygen isotopic compositions of calcite in lake sediments. $\delta^{13} \mathrm{C}$ and $\delta^{18} \mathrm{O}$ values of calcite in cored sediments are summarized in Table 4. The former range from -10.6 to 
Table 4. $\delta^{13} \mathrm{C}$ and $\delta^{18} \mathrm{O}$ of calcite from Lake Vanda sediments

\begin{tabular}{c|c|c|c}
\hline Sample No. & Depth $(\mathrm{m})^{*}$ & $\delta^{13} \mathrm{C}(\%)$ & $\delta^{18} \mathrm{O}(\%)$ \\
\hline Botton surface & 68.3 & & \\
$6-1$ & 68.48 & -3.5 & +2.9 \\
$1-\mathrm{a}$ & 68.83 & +10.4 & +1.4 \\
$5-\mathrm{f}$ & 68.87 & +10.8 & +1.7 \\
$6-\mathrm{b}$ & 68.98 & +11.4 & +1.7 \\
$1-4$ & 69.08 & +11.6 & +1.0 \\
$6-2$ & 69.10 & +10.3 & +0.8 \\
$6-\mathrm{a}$ & 69.48 & +10.3 & +0.9 \\
$1-5$ & 69.56 & +4.4 & +0.2 \\
$6-3$ & 70.05 & +1.9 & -0.5 \\
$2-\mathrm{c}$ & 70.08 & -5.3 & -1.3 \\
$2-6$ & 70.23 & -4.2 & -1.5 \\
$7-5$ & 71.17 & -9.3 & +1.0 \\
$11-7$ & 71.50 & +0.3 & +1.7 \\
$4-\mathrm{e}$ & 72.00 & -7.6 & -2.3 \\
$4-9$ & 72.15 & +6.4 & -2.1 \\
$16-15$ & 74.58 & -10.6 & +6.8 \\
\hline
\end{tabular}

* Below the lake surface.

Fig. 8. Vertical variations of $\delta^{13} \mathrm{C}$ for calicte from Lake Vanda sediments.

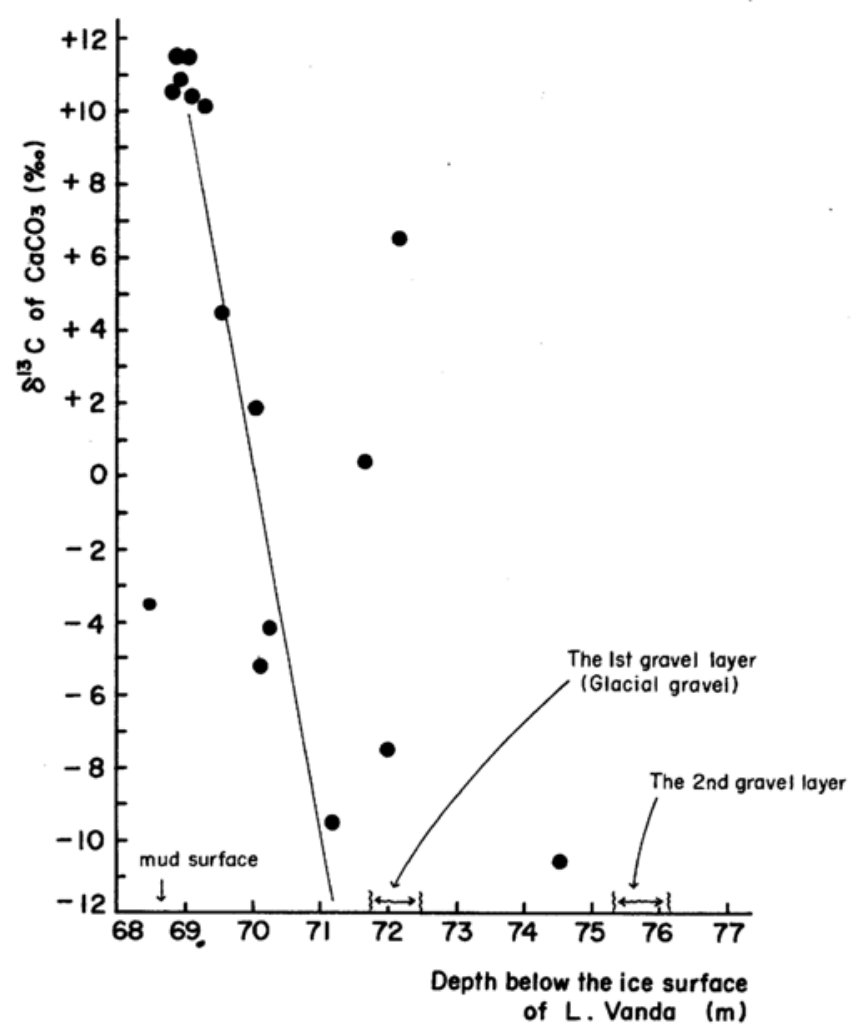

$+11.6 \%$ and the latter from -2.3 to $+6.8 \%$. The range of $\delta^{13} \mathrm{C}$ values in cored sediments is exceptionally wide, $20 \%$, for a field. In the sediment above the first gravel layer, however, $\delta^{13} \mathrm{C}$ values increase linearly with decreasing depth as shown in Fig. 8 . This variation of $\delta^{13} \mathrm{C}$ values from the first gravel layer to the surface sediment can be explained only by that deposition and dissolution of $\mathrm{CaCO}_{3}$ repeated in the sedimentary process on 
evaporation of lake water and on supply of water and atmospheric $\mathrm{CO}_{2}$. An example of the explanation is given as follows.

Isotopic fractionations between $\mathrm{CaCO}_{3}$ and $\mathrm{CO}_{2}$ and between $\mathrm{HCO}_{3}^{-}$and $\mathrm{CO}_{2}$ (gas) were calculated for carbon isotopic exchange equilibria by BoTTINGA (1969) and MooK et al. (1974). Calcium carbonate, which was deposited initially by evaporation of lake

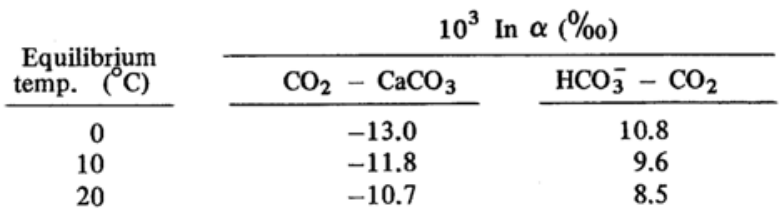

water after the first gravel layer was formed, is assumed to have a $\delta^{13} \mathrm{C}$ value of $-10 \%$ o from the values of calcium carbonates just above the first gravel layer. During the following warm period, inflow of glacial melt water and atmospheric $\mathrm{CO}_{2}$ resulted in partial dissolution of $\mathrm{CaCO}_{3}$. Assuming $\delta^{13} \mathrm{C}$ of atmospheric $\mathrm{CO}_{2}$ to be constantly $-7.0 \%$, we can get the $\delta^{13} \mathrm{C}$ value of $\mathrm{HCO}_{3}^{-}$dissolved in water to be $-8.5 \%$. Furthermore, during the following cold period, lake water was evaporated again and deposited $\mathrm{CaCO}_{3}$ to form another salt layer at a depth shallower than that of the first salt layer. In this process, 2 mols of

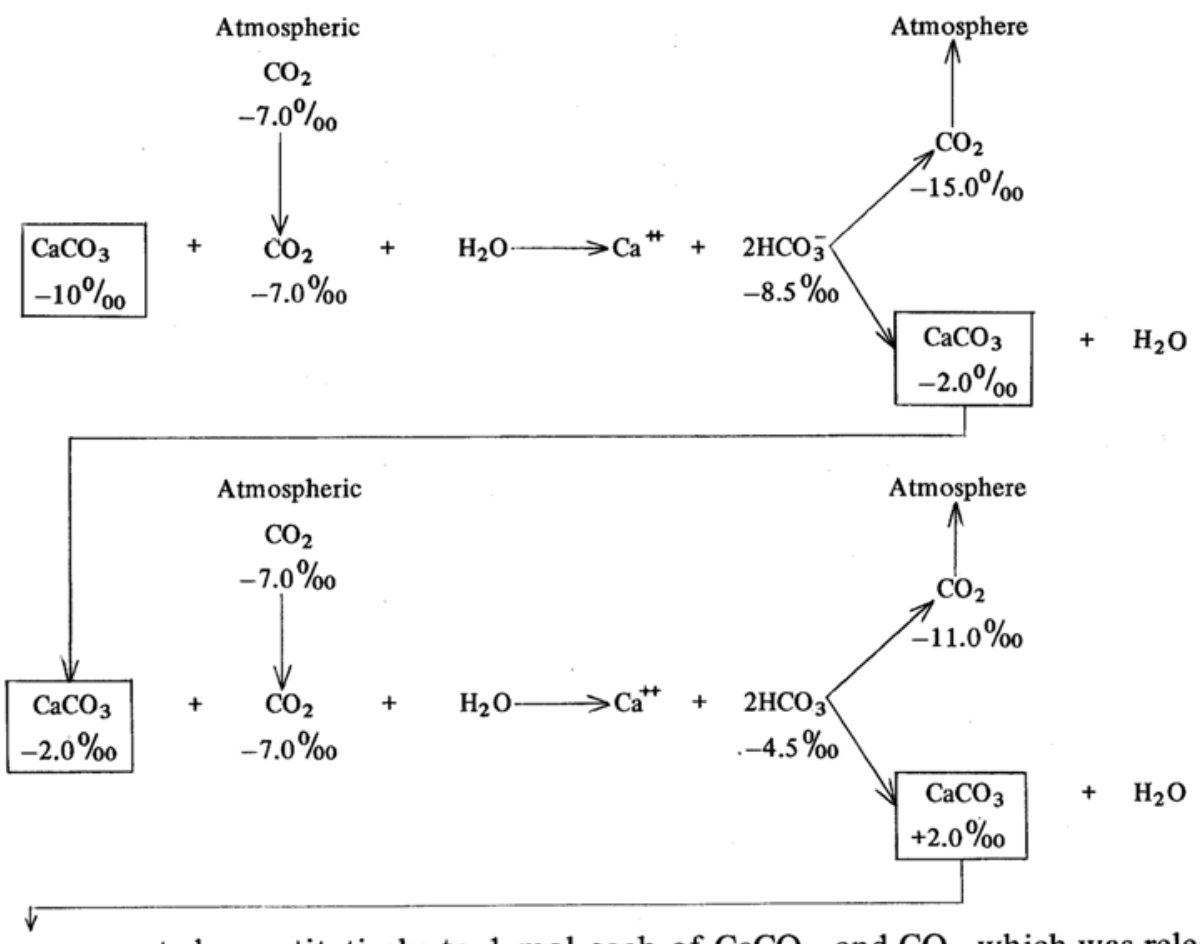

$\mathrm{HCO}_{3}^{-}$were converted quantitatively to $1 \mathrm{~mol}$ each of $\mathrm{CaCO}_{3}$ and $\mathrm{CO}_{2}$ which was released to the atmosphere. Assuming an isotopic exchange equilibrium between $\mathrm{CaCO}_{3}$ and $\mathrm{CO}_{2}$ at $0^{\circ} \mathrm{C}$, we can calculate $-2.0 \%$ of $\delta^{13} \mathrm{C}$ for deposited $\mathrm{CaCO}_{3}$, which is much heavier than that just above the first gravel layer. Another set of partial dissolution and deposition 
of $\mathrm{CaCO}_{3}$ increase the $\delta^{13} \mathrm{C}$ to $+2.0 \%$. Thus, after repeated dissolution and deposition $\mathrm{CaCO}_{3}$ is progressively enriched in ${ }^{13} \mathrm{C}$. We can explain this isotopic distribution in sediments similarly by assuming the isotopic equilibrium between $\mathrm{CaCO}_{3}$ and $\mathrm{HCO}_{3}^{-}$, too.

Another possible explanation for $\delta^{13} \mathrm{C}$ variation of $\mathrm{CaCO}_{3}$ with depth is that $\mathrm{CaCO}_{3}$ is dissolved by acid water, as expected from the low $\mathrm{pH}$ value, 5.6, of present bottom water in the lake, and alternate deposition and dissolution are repeated in the same way as above. This process also implies that $\mathrm{CaCO}_{3}$ becomes progressively enriched in ${ }^{13} \mathrm{C}$ toward the later stage of deposition as follows:

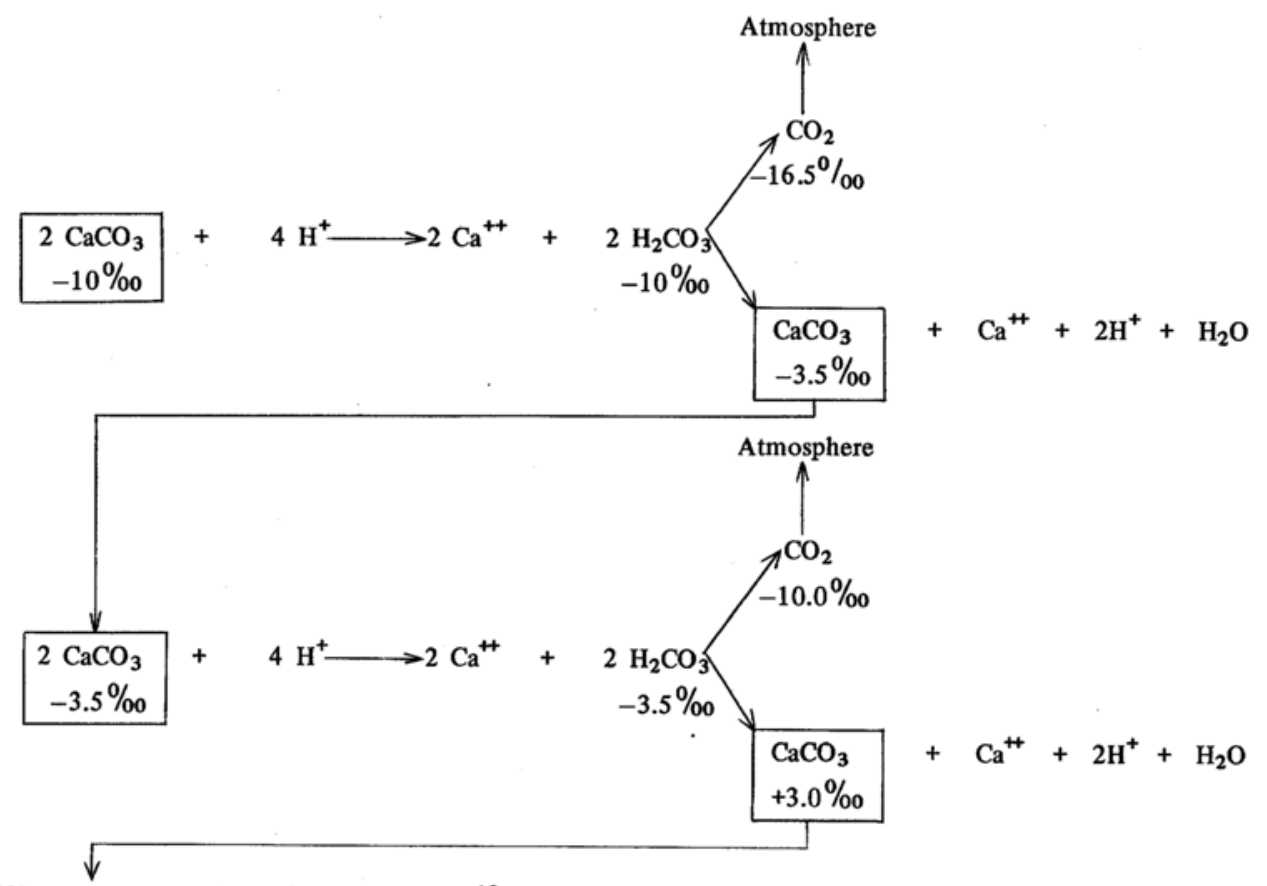

The vertical distribution of $\delta^{18} \mathrm{O}$ values for $\mathrm{CaCO}_{3}$ in cored sediments is shown in Fig. 9. $\delta^{18} \mathrm{O}$ values increase linearly with decreasing depth of sediments above the first gravel layer in the same manner as that of $\delta^{13} \mathrm{C}$. This variation is elucidated by progressive deposition of $\mathrm{CaCO}_{3}$. As is well known, oxygen in calcium carbonate is in isotopic equilibrium with water in which the $\mathrm{CaCO}_{3}$ is precipitated. $\delta^{18} \mathrm{O}$ values of $\mathrm{CaCO}_{3}$ are 33.9 and $28.0 \%$ larger than that of water in isotopic equilibrium at 0 and $25^{\circ} \mathrm{C}$, respectively (BotTINGA, 1968). If $\mathrm{Ca}^{++}$had been initially trapped in the lake basin by the isolation of the lake from the ocean, the progressive formation of salt layers containing $\mathrm{CaCO}_{3}$ in sediments decreases the amount of $\mathrm{Ca}^{++}$dissolved in the lake water. In the later formation of salt layer, therefore, further concentration of the lake water is necessary to precipitate $\mathrm{CaCO}_{3}$. This means that $\delta^{18} \mathrm{O}$ values of the water from which $\mathrm{CaCO}_{3}$ have been precipitated increase with progress in the formation of salt layers, resulting in a gradual increase in $\delta^{18} \mathrm{O}$ of $\mathrm{CaCO}_{3}$ toward shallower salt bands. $\delta^{18} \mathrm{O}$ values of $\mathrm{CaCO}_{3}$ above the first gravel layer range from -1.5 to $+2.9 \%$ and suggest that the carbonate was deposited or recrystallized in isotopic equilibrium with fresh water distributed in this area.

Thus on the basis of isotopic data for cored sediments, it is concluded that salts in the lake had been derived directly from the ocean and the lake level has largely fluctuated 
several times according to climatic changes after the isolation of the lake from the ocean.

Fig. 9. Vertical variations of $\delta^{18} \mathrm{O}$ for calcite from Lake Vanda sediments.

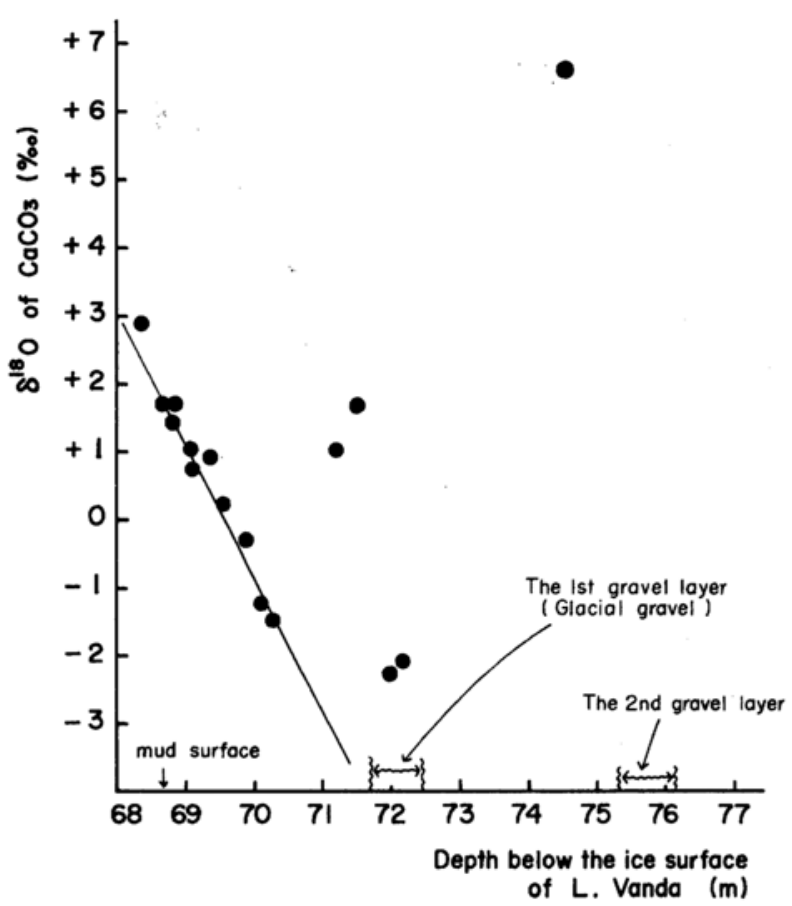
Possible origins of salts distributed around Lake Vanda Evaporites composed of
several kinds of minerals occur on the ice-free ground surface around Lake Vanda. They were collected from the shore line of the lake, the Canopus bench, Bull Pass and the Dais. Evaporites can be grouped into three types by the mode of occurrence; (a) thin salt layers coating the surface of rock debris, (b) plate-like salt aggregates in soils and (c) salts occurring in veins of dolerite found on the wall rocks of the Dais. The last type of salt occurs with zeolite (laumontite) and sometimes contains idiomorphic crystals of calcite.

$\delta^{34} \mathrm{~S}$ values of sulfate minerals, gypsum and thenardite, are presented in Table 5. Sulfate minerals found near the shore line of Lake Vanda occur as thin salt layers coating the surface of rock debris and show $\delta^{34} \mathrm{~S}$ values of +18.9 to $+20.3 \%$, which suggest that these sulfates are marine in origin. They are considered to have been deposited from the lake water. On the other hand, the values of sulfate minerals from veins in dolerite of the Dais and from soils widely distributed at the Canopus bench ranges from +15.0 to $+17.8 \%$ and from +14.1 to $+16.3 \%$, respectively. Since sulfates from the Dais are supposed to be hydrothermal in origin from the occurrence of zeolite, their $\delta^{34} \mathrm{~S}$ values are considered to represent those of hydrothermal sulfate in this area. Sulfate minerals occurring on the Canopus bench show the lowest $\delta^{34} \mathrm{~S}$ values. Although the origin can not be definitely identified only by the isotopic composition, the following two suppositions are possible. (i) They are supposed to have been derived by wind from the ocean, because they have $\delta^{34} \mathrm{~S}$ values similar to those of the atmospheric sulfate. (ii) They were supplied from the surface water of the lake during a period of high water level and remained on the 
bench when the lake surface was lowered to the present level. The later supposition is derived from similarity of $\delta^{34} \mathrm{~S}$ values between sulfate. minerals and $\mathrm{SO}_{4}^{=}$in the present surface water of the lake.

Table 5. ${ }^{34} S$ values of sulfate minerals in salts coating rock debris and soil around Lake Vanda, Wright Valley

\begin{tabular}{c|c|c}
\hline Sample No. & $\delta^{34} \mathrm{~S}(\%)$ & $\begin{array}{c}\text { Mineral } \\
\text { composition }\end{array}$ \\
\hline Near the shore of Lake Vanda & +19.2 & Gy. Cal. \\
73112406 & +18.9 & Th. Gy. \\
112411 & +19.9 & Gy. \\
112413 & +20.3 & Gy. \\
112606 & +19.6 & Gy. \\
112607 & +20.0 & Gy. \\
112901 & & \\
Dais and near Dais & +16.1 & Th. \\
73112501 & +17.8 & Gy. Th. \\
120202 & +17.0 & Gy. \\
120210 & +16.6 & Th. \\
120214 & +17.6 & Gy. \\
120309 & +15.0 & Th. Gy. \\
120312 & +17.6 & Gy. \\
120313 & +15.2 & Gy. \\
120319 & & \\
& & \\
73112301 & +14.1 & Th. Gy. \\
112303 & +14.5 & Th. \\
112304 & +14.4 & Gy. Th. \\
112305 & +16.3 & Th. \\
112308 & &
\end{tabular}

Gy. : Gypsum, Th. : Thenardite.

Above results suggest that salts distributed in this area were derived from various sources and they do not constitute the source for the salts contained in Lake Vanda.

Carbonate minerals contained in evaporites also were analyzed for carbon and oxygen isotope compositions, and the results are summarized in Table 6 . The relationship between $\delta^{13} \mathrm{C}$ and $\delta^{18} \mathrm{O}$ of them is shown graphically in Fig. $10 . \delta^{13} \mathrm{C}$ values distinctly differ according to their occurrence and localities. Calcium carbonate occurring as thin salt layers coating rock debris near the shore of Lake Vanda shows the highest $\delta^{13} \mathrm{C}$ values from +14 to $+18 \%$ and the lowest $\delta^{18} \mathrm{O}$ values from -0.2 to $+4.5 \%$. The high $\delta^{13} \mathrm{C}$ and the low $\delta^{18} \mathrm{O}$ values suggest that $\mathrm{CaCO}_{3}$ were recrystallized many times in fresh water. Calcium carbonates, which occur ${ }^{-}$with zeolite or as idiomorphic crystals in veins at the Dais, have comparatively constant values of $\delta^{13} \mathrm{C}$ and $\delta^{18} \mathrm{O}$. This suggests that they are hydrothermal in origin. Both $\delta^{13} \mathrm{C}$ and $\delta^{18} \mathrm{O}$ values of carbonates coating the surface of rock debris which are distributed on the top of the Dais, on the Canopus bench and at the Bull Pass suggest that they are marine in origin as shown in Fig. 10. Since sampling sites are located at higher altitudes, carbonates are considered not to have been subjected to recrystallization in fresh water.

Various sources for carbonate minerals widely distributed in this area were recognized from isotopic studies as mentioned above. Further detailed studies, however, are required to explain the genetic relation between $\mathrm{CaCO}_{3}$ in Lake Vanda and in the evaporite. 
Table 6. $\delta^{13} \mathrm{C}$ and $\delta^{18} \mathrm{O}$ values of carbonate minerals distributed around Lake Vanda, Wright Valley

\begin{tabular}{|c|c|c|c|c|}
\hline Sample No. & $\delta^{13} \mathrm{C}(\%)$ & $\delta^{18} \mathrm{O}(\%)$ & $\begin{array}{c}\text { Mineral } \\
\text { composition }\end{array}$ & Occurrence \\
\hline \multicolumn{3}{|c|}{ Near the shore of Lake Vanda } & & \multirow{9}{*}{$\begin{array}{l}\text { Salts coating } \\
\text { boulders and } \\
\text { soils. }\end{array}$} \\
\hline 73112402 & +14.4 & -0.1 & Cal. & \\
\hline 112403 & +14.4 & -0.2 & Cal. & \\
\hline 112404 & +14.4 & +4.5 & Cal. & \\
\hline 112406 & +11.4 & -0.4 & Cal. & \\
\hline 112601 & +14.5 & +0.5 & Cal. & \\
\hline 112602 & +7.8 & +3.1 & Cal. & \\
\hline 112904 & +15.5 & +1.0 & Cal. & \\
\hline 120330 & +17.6 & +0.4 & Cal. & \\
\hline \multicolumn{5}{|l|}{ Dais } \\
\hline 73120301 & -12.4 & +4.3 & Zeol. & \multirow{4}{*}{$\begin{array}{l}\text { White crystals } \\
\text { in veins. }\end{array}$} \\
\hline 120322 & -12.7 & +3.0 & Zeol. & \\
\hline 120323 & -9.6 & +5.6 & Zeol. & \\
\hline 120329 & -10.7 & +2.5 & Zeol. & \\
\hline 120305 & -8.5 & +2.1 & Cal. & \multirow{3}{*}{$\begin{array}{l}\text { Idiomorphic } \\
\text { calcite. }\end{array}$} \\
\hline 120326 & -12.9 & +2.6 & Cal. & \\
\hline 120307 & -14.4 & +4.2 & Cal. & \\
\hline 120310 & +9.0 & +22.3 & Cal. & \multirow{4}{*}{$\begin{array}{l}\text { Salts coating } \\
\text { boulders. } \\
\text { White crystal } \\
\text { from the top } \\
\text { of Dais. }\end{array}$} \\
\hline 120316 & +1.5 & +16.9 & Cal.- & \\
\hline 120316 & +1.9 & +19.6 & Dol. & \\
\hline \multicolumn{4}{|l|}{ Canopus } & \\
\hline 73112318 & +8.7 & +17.8 & Cal. & \multirow{3}{*}{$\begin{array}{l}\text { Salts coating } \\
\text { boulders. } \\
n\end{array}$} \\
\hline \multicolumn{4}{|l|}{ Bull pass } & \\
\hline 73112714 & +8.5 & +21.5 & Cal. & \\
\hline
\end{tabular}

Cal. : Calcite, Dol. : Dolomite, Zeol. : Zeolite (Laumontite).

Fig. 10. Relationship between $\delta^{13} \mathrm{C}$ and $\delta^{18} \mathrm{O}$ of calcite from the Lake Vanda area, Wright Valley.

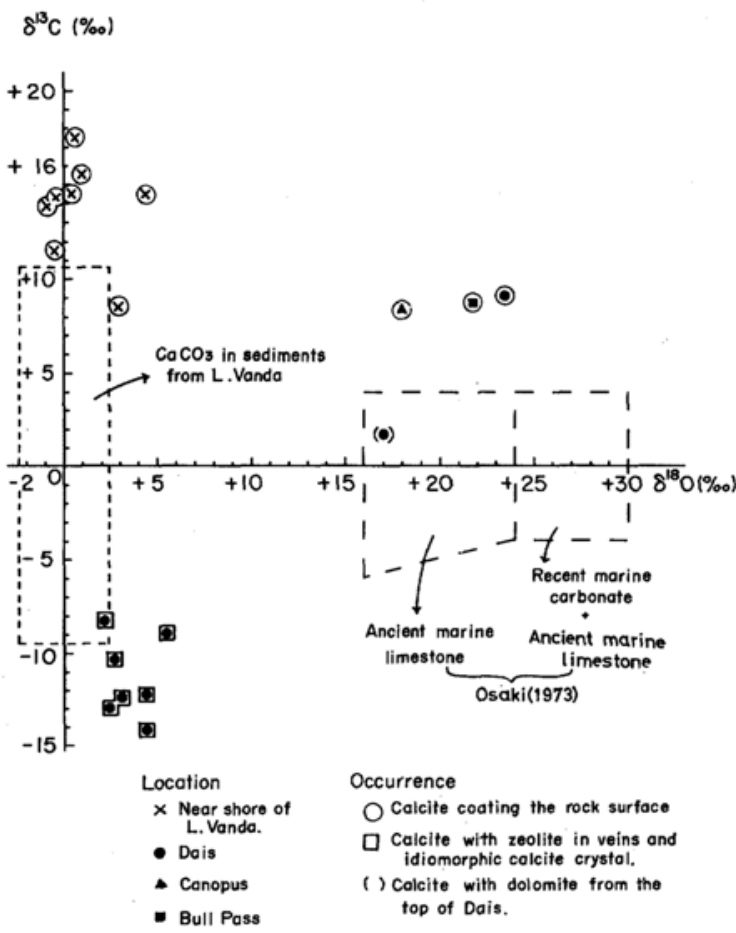




\section{ConClusions}

Significant conclusions from the foregoing discussion are summarized as follows:

1) Present day water of Lake Vanda is clearly neither marine nor volcanic in origin in spite of the high salt concentration and water temperature, but fresh water in origin.

2) Salts contained in the lake were transported with sea water from the ocean and were not derived by wind from the ocean.

3) Origins of gypsum and calcite (dolomite) in evaporite distributed around Lake Vanda differ according to their occurrences and localities: hydrothermal, marine or marine aerosol. These salts, however, have not appreciably contributed to those in Lake Vanda. 4) Historical events in the past lake were recognized Before the formation of the first gravel layer (glacial gravel) in lake sediments, sea water was present in the lake basin as a fjord. When the glacial gravel was deposited in the basin by glaciation after the Tertiary, the sea water was isolated from the ocean. The sea water evaporated to form salt deposits in cold climate and subsequently the basin was flooded by glacial melt water supposedly from Wright Upper Glacier in a warm climate. After the following evaporation and flooding of water had been repeated, Wright Lower Glacier was formed by upheaval in the east of Lake Vanda and the lake have been flooded by melt water.

\section{ACKNOWLEDGMENTS}

The authors are grateful to Professor S. OANA of Nagoya University for his helpful discussions and critical reading the manuscript. We thank Dr. T. TORII of Japan Polar Research Association and Dr. H. MORIKAWA of Tokyo Institute of Technology for their great assistance in collecting samples. Thanks are also due to Messrs. S. OONO and K. NAKAYAMA for their kind assistance at the McMurdo Station and in Dry Valleys.

This work was financially supported by National Institute of Polar Research, Japan and the National Science Foundation, U.S.A.

\section{REFERENCES}

Angino, E. E., ARmitage, K. B. and TASH, J. C. (1962) Chemical stratification in Lake Fryxel, Victoria Land, Antarctica. Science 138, 34-36.

Angino, E. E. and ARMitAGE, K. B. (1963) A geochemical study of lakes Bonney and Vanda, Victoria Land, Antarctica. J. Geol. 71, 89-95.

Angino, E. E., ARmitage, K. B. and TASH, J. C. (1965) A chemical and limnological study of Lake Vanda, Victoria Land, Antarctica. Kans. Univ. Sci. Bull. 45, 1097-1118.

A RmitAgE, K. B. and House, H. B. (1962) A limnological reconnaissance in the area of McMurdo Sound, Antarctica. Limnol. Oceanogr. 7, 36-41.

BOTTINGA, Y. (1968) Calculation of fractionation factors for carbon and oxygen isotopic exchange in the system calcite-carbon dioxide-water. J. Phys. Chem. 72, 800-809.

BotTINGA, Y. (1969) Calculated fractionation factors for carbon and hydrogen isotope exchange in the system calcite-carbon dioxide-graphite-hydrogen-water vapor. Geochim. Cosmochim. Acta 33, 49-64.

CraIG, H. (1966) Origin of the saline Lakes in Victoria Land, Antarctica. Trans. Am. Geophys. Union 47, 112-113.

DANSGAARD, W. (1954) The ${ }^{18} \mathrm{O}$ abundance in fresh water. Geochim. Cosmochim. Acta 6, 241-260.

DANSGAARD, W. (1964) Stable isotopes in precipitation Tellus 16, 436-468.

Friedman, I., REDFIELD, A. C., SCHOEN, B. and HARRIS, J. (1964) The variation of the deuterium content of natural waters in the hydrologic cycle. Rev. Geophys. 2, 177-224. 
HoARE, R. A. (1966) Problems of heat transfer in Lake Vanda, a density stratified Antarctic lake. Nature 210, 787-789.

HOLSER, W. T. and KAPLAN, I. R. (1966) Isotope geochemistry of sedimentary sulfates. Chem. Geol. 1, 93-135.

Johnson, S. J., DansgaARD, W., Clausen, H. B. and Langway, C. C. (1972) Oxygen isotope profiles through the Antarctic and Greenland ice sheets. Nature 235, 429-434.

JONES, L. M. and FAURE, G. (1967) Origin of the salts in Lake Vanda, Wright Valley, Southern Victoria Land, Antarctica. Earth Planet. Sci. Lett. 3, 101-106.

LyON, G. L. (1974) Stable isotope analyses of ice from DVDP 3. Dry Valley Drilling Project, Bull. No. 3, 160-169.

Mook, W. G., Bommerson, J. C. and Staverman, W. H. (1974) Carbon isotope fractionation between dissolved bicarbonate and gaseous carbon dioxide. Earth Planet. Sci. Lett. 22, 169-176.

MorIKAWA, H. and OSSAKA, J. (1974) The distribution of secondary minerals at Lake Vanda. Dry Valley Drilling Project, Bull. No.4, 18.

NAKAI, N. and JENSEN, M. L. (1964) The kinetic isotope effect in the bacterial reduction and oxidation of sulfur. Geochim. Cosmochim. Acta 28, 1893-1912.

NAKAI, N. and JenSEN, M. L. (1967) Source of atmospheric sulfur compounds. Geochem. J. 1, 199-210.

Nelson, C. and Willson, A. (1972) Bathymetry and bottom sediment of Lake Vanda, Antarctica. Antarctic J. July-Aug., 97-102.

Nichols, R. L. (1963) Geologic features demonstrating aridity of McMurdo Sound area, Antarctica. Am. J. Sci. 261, 20-31.

OSAKI, S. (1973) Carbon and oxygen isotopic compositions of Tertiary and Permian dolomites in Japan. Geochem. J. 6, 163-177.

RagotzKie, R. A. and Likeno, G. E. (1964) The heat balance of two Antarctic lakes. Limnol. Oceanogr. 9, 412-426.

TORII, T., YAMAGATA, N. and Chо, T. (1967) Report of the Japanese Summer Parties in Dry Valleys, Victoria Land, 1963-1965 II. General description and water temperature data for the lakes. Antarctic Rec. 28, 1-14.

WhITE, D. E., BARNES, I. and O'NeIL, J. R. (1973) Thermal and mineral waters of non-meteoric origin, California Coast Ranges. Geol. Soc. Am. Bull. 84, 547-560.

Wilson, A. T. and Wellman, W. H. (1962) Lake Vanda: an antarctic lake. Nature 196, 1171-1173.

Yamagata, N., TORII, T. and MURATA, S. (1967) Report of the Japanese Summer Parties in Dry Valleys, Victoria Land, 1963-1965 V. Chemical composition of lake waters. Antarctic Rec. 29, 2339-2361.

Yoshida, Y., YUSA, Y., MORIWAKI, K. and TORII, T. (1971) Report of the Japanese Summer Parties in Dry Valleys, Victoria Land IX. A preliminary report of geophysical study of Dry Valleys in 1970-1971. Antarctic Rec. 42, 65-88. 